\title{
Analisis Zakat Produktif terhadap Kesejahteraan Mustahik (Studi pada Lembaga Amil Zakat Infaq Shodaqoh NU Yogyakarta)
}

\author{
Abdul Salam dan Desi Risnawati \\ Fakultas Agama Islam Universitas Alma Ata \\ Jl. Brawijaya No.99 Yogyakarta \\ Email: salam.eretan@gmail.com
}

\begin{abstract}
This research aimed at finding analysing productive Zakah management and its effect on mustahik wealthy improvement. The research method used in this research is qualitative descriptive with field based approach. Information and data resources in this research are LAZISNU Yogyakarta and 42 Mustahik who received Zakah. Triangulation (observation, interview and documentation) is used to collect the data. The data in this research is analysed through three steps; data reduction, data presentation and drawing conclusions. The results of the analysis show that the management of productive zakat in LAZISNU Yogyakarta not only receives, collects and distributes productive zakat funds, but also provides supervision and assistance to Mustahik. The impact of Mustahik welfare at the prosperous family level I reached $38.5 \%$, prosperous family stage level II reached $28.5 \%$, the prosperous family level III reached $16.5 \%$ and the prosperous family level III Plus reached $16.5 \%$
\end{abstract}

Keywords: Productive Zakah, Zakat Analysis, Mustahik Welfare

\begin{abstract}
Abstrak
Penelitian ini bertujuan untuk mengetahui dan menganalisa pengelolaan zakat produktif serta dampaknya terhadap peningkatan kesejahteraan mustahik. Adapun metode penelitian yang peneliti gunakan adalah deskriptif kualitatif dengan penelitian lapangan. Informasi dan sumber data dalam penelitian ini adalah LAZISNU Yogyakarta dan 42 mustahik yang menerima dana zakat. Alat pengumpulan data yang digunakan adalah triangulasi (observasi, wawancara dan dokumentasi). Teknik analisis data penelitian ini melalui tiga tahapan yakni reduksi data, penyajian data, dan penarikan kesimpulan. Hasil analisis menunjukan bahwa pengelolaan zakat produktif LAZISNU Yogyakarta tidak hanya menerima, mengumpulkan dan mendistribusikan dana zakat produktif, akan tetapi juga memberikan pengawasan dan pendampingan kepada mustahik. Sedangkan dampak kesejahteraan mustahik pada tingkat keluarga sejahtera I mencapai $38,5 \%$, tingkat keluarga sejahtera II mencapai 28,5\%, tingkat keluarga sejahtera III mencapai 16,5\% dan tingkat keluarga sejahtera III Plus mencapai 16,5\%.
\end{abstract}

Keywords: Zakat Produktif, Analisis Zakat, Kesejahteraan Mustahik

\section{PENDAHULUAN}

Kemiskinan menjadi sesuatu yang akrab dengan negara-negara berkembang, termasuk Indonesia. Kemiskinan adalah salah satu dari sekian banyak problematika bangsa yang harus segera diselesaikan, khususnya di bidang ekonomi. Menjadi suatu kepastian bahwasanya penanggulangan kemiskinan menjadi bahasan paling penting dalam perbaikan negara (Ramadhan, 2016). Islam sebagai Ad-diin telah menawarkan beberapa doktrin bagi manusia yang berlaku secara universal dengan dua ciri dimensi, yaitu kebahagiaan dan kesejahteraan hidup di dunia serta kebahagiaan dan kesejahteraan hidup di akhirat (Sartika, 2008).

Kesejahteraan merupakan suatu kondisi yang menjadi harapan bagi setiap warga negara. Namun pada kenyataannya tidak semua warga negara dapat dengan mudah mendapatkan kesejahteraan. Berbicara tentang masalah kesejahteraan dalam Islam, tentunya 
hal tersebut tidak dapat dilepaskan dengan pembahasan mengenai zakat (Nafiah, 2015).

Zakat adalah kewajiban yang harus ditunaikan seorang muslim/muslimah sebagai pelaksanaan rukun ketiga dari lima rukun Islam di mana keberadaan zakat itu sendiri memiliki tujuan penanaman nilai keimanan. Jadi, zakat merupakan kewajiban agama yang harus dibayarkan oleh setiap muslim yang telah memenuhi ketentuan persyaratan dalam keadaan apa pun. Secara praktis, zakat adalah satu amalan ibadah yang berdimensi sosialekonomi. Karena dalam praktiknya, zakat digunakan sebagai sarana untuk membantu anggota masyarakat yang mengalami kesulitan sosial-ekonomi. Zakat menjadi wahana yang membentuk masyarakat untuk bekerjasama dan berperan sebagai penjamin perlindungan sosial bagi masyarakat (Fitri, 2017).

Salah satu dasar hukum yang menunjukkan diperintahkannya zakat adalah firman Allah SWT dalam surat At-Taubah ayat 103 yang artinya "Ambillah zakat dari sebagian harta mereka, dengan zakat itu kamu membersihkan dan mensucikan mereka dan mendoalah untuk mereka. Sesungguhnya doa kamu itu (menjadi) ketentraman jiwa bagi mereka. Dan Allah maha mendengar lagi maha mengetahui".

Zakat memiliki peranan yang sangat strategis dalam upaya pengentasan kemiskinan atau pembangunan ekonomi. Berbeda dengan sumber keuangan untuk pembangunan yang lain, zakat tidak memiliki umpan balik apapun kecuali ridha dan mengharap pahala dari Allah SWT. Namun demikian, bukan berarti mekanisme zakat tidak ada sistem kontrolnya. Nilai strategis zakat dapat dilihat melalui: Pertama, zakat merupakan panggilan agama. Ia merupakan cerminan dari keimanan seseorang. Kedua, sumber keuangan zakat tidak akan pernah berhenti. Artinya orang yang membayar zakat, tidak akan pernah habis dan yang telah membayar setiap tahun atau periode waktu yang lain akan terus membayar. Ketiga, zakat secara empirik dapat menghapus kesenjangan sosial dan sebaliknya dapat menciptakan redistribusi aset dan pemerataan pembangunan (Sartika, 2008).

Sebagai negara dengan jumlah penduduk muslim terbesar di dunia, isu zakat di Indonesia tidak hanya berhenti pada perspektif religius saja, namun juga bisa disikapi sebagai realitas sosial yaitu sebagai sumber daya nasional yang perlu dikelola dan diberdayakan secara amanah dan benar. Artinya, zakat adalah sumber daya ekonomi yang perlu dikelola dengan penuh tanggung jawab dan ditempatkan sebagai modal sosialekonomi untuk usaha-usaha memberdayakan umat (masyarakat). Menurut Forum Zakat Indonesia, potensi zakat di Indonesia mencapai Rp 300 triliun per tahun. Namun dari potensi yang besar itu, baru tercapai sekitar Rp 1,8 triliun per tahun (Fitri, 2017).

Menurut data dari Badan Pusat Statistik, 2017 bahwa garis kemiskinan di Daerah Istimewa Yogyakarta pada Maret 2017 sebesar Rp 374.009,- per kapita perbulan. Sementara garis kemiskinan pada Maret 2016 sebesar Rp 354.084,- perkapita perbulan, atau garis kemiskinan mengalami kenaikan sekitar 5,63 persen bila dibandingkan kondisi September 2016 yang sebesar Rp 360.169,- per kapita per bulan maka dalam kurun satu semester terjadi kenaikan sebesar 3,84 persen.

Jika dikelola dengan baik zakat dapat menjadi salah satu push faktor bagi perbaikan kondisi ekonomi masyarakat, karena dengan adanya distribusi zakat akan terjadi pertumbuhan kesejahteraan pada golongan penerima zakat (Khasanah, 2010).

Indonesia merupakan suatu negara dengan mayoritas penduduk beragama Islam hal ini berarti mayoritas penduduk Indonesia berkewajiban membayar zakat setiap tahunnya, secara otomatis potensi jumlah dan pendayagunaan zakat di Indonesia khususnya dalam upaya meningkatkan kesejahteraan sangatlah besar (Nafiah, 2015).

Potensi tersebut tentunya sudah disadari oleh pemerintah, hal ini terlihat dengan adanya dasar hukum/undang-undang tentang zakat yang salah satu diantaranya adalah Undangundang No 23 tahun 2011 tentang pengelolaan zakat. Untuk mendorong terlaksananya Undang-undang tersebut pemerintah juga memfasilitasi dengan dibentuknya Lembaga Amil Zakat Infaq dan Shodaqah (LAZIS) yang bertugas untuk mengelola zakat, infaq dan shodaqoh disetiap daerah yang berada di Indonesia (Nafiah, 2015). 
Saat ini, jumlah Organisasi Pengelola Zakat (OPZ) yang tercatat di Kementerian Agama Provinsi Yogyakarta berjumlah lebih dari 28 lembaga baik yang berupa BAZDA, LAZ maupun LAZIS. Meski demikian belum ada data akurat mengenai strategi fundraising, pengelolaan dan pendistribusian dana serta pola pengawasan dan transparansi sebagai sebuah kesatuan yang sistematik dari masingmasing Organisasi Pengelola Zakat di Daerah Istimewa Yogyakarta (Kholis ed al, 2013)

Untuk memaksimalkan potensi zakat dalam upaya peningkatan kesejahteraan masyarakat, pengelolaan zakat sekarang ini dilakukan dengan dua cara yaitu pengelolaan zakat secara konsumtif dan produktif. Pengelolaan zakat secara konsumtif adalah pengumpulan dan pendistribusian yang dilakukan dengan tujuan memenuhi kebutuhan dasar ekonomi para mustahik berupa pemberian bahan makanan dan lainlain serta bersifat pemberian untuk dikonsumsi secara langsung, sedangkan pengelolaan zakat secara produktif adalah pengelolaan zakat dengan tujuan pemberdayaan dan biasa dilakukan dengan cara bantuan modal pengusaha lemah, pembinaan, pendidikan gratis dan lain-lain (Soemitra, 2009).

Zakat yang diberikan kepada mustahik akan berperan sebagai pendukung peningkatan ekonomi mereka apabila dikonsumsikan pada kegiatan produktif. Pendayagunaan zakat produktif sesungguhnya mempunyai konsep perencanaan dan pelaksanaan yang cermat seperti mengkaji penyebab kemiskinan, ketidakadaan modal kerja, dan kekurangan lapangan kerja, dengan adanya masalah tersebut maka perlu adanya perencanaan yang dapat mengembangkan zakat bersifat produktif tersebut (Fajri, 2010).

Pengembangan zakat bersifat produktif dengan cara dijadikannya dana zakat sebagai modal usaha, untuk pemberdayaan ekonomi penerimanya, dan supaya fakir miskin dapat menjalankan atau membiayai kehidupannya secara konsisten. Dengan dana zakat tersebut fakir miskin akan mendapatkan penghasilan tetap, meningkatkan usaha, mengembangkan usaha serta mereka dapat menyisihkan penghasilannya untuk menabung (Sartika, 2008).
Dana zakat untuk kegiatan produk produktif akan lebih optimal bila dilaksanakan oleh lembaga filantropi Islam seperti yang dikelola oleh Lembaga Amil Zakat Infaq dan Shodaqah Nahdlotul Ulama (LAZISNU), dimana LAZISNU sebagai organisasi yang terpercaya untuk pengalokasian, pendayagunaan, dan pendistribusian dana zakat, mereka tidak memberikan zakat begitu saja melainkan mereka mendampingi, memberikan pengarahan serta pelatihan agar dana zakat tersebut benar-benar dijadikan modal kerja sehingga penerima zakat tersebut memperoleh pendapatan yang layak dan mandiri. Dana zakat produktif $60 \%$ dana yang diperoleh LAZISNU Yogyakarta digunakan untuk kegiatan produktif, sedangkan yang $40 \%$ digunakan untuk kegiatan konsumtif (Sartika, 2008).

Dengan berkembangnya usaha kecil menengah dengan modal berasal dari zakat akan menyerap tenaga kerja dan berkembangnya usaha para mustahik. Hal ini dapat mengurangi pengangguran, berkurangnya angka pengangguran akan berdampak pada meningkatnya daya beli masyarakat akan diikuti oleh pertumbuhan produksi, pertumbuhan sektor produksi inilah yang akan menjadi salah satu indikator adanya pertumbuhan ekonomi.

Dengan demikian LAZISNU Yogyakarta mempunyai peran untuk mengelola, dan mendistribusikan dana zakat menjadi dana zakat produktif untuk bantuan modal usaha dalam meningkatkan kesejahteraan para mustahiknya. Maka dari itu perlu adanya penelitian apakah dengan adanya program zakat produktif di LAZISNU dapat meningkatkan kesejahteraan para mustahik di Daerah Istimewa Yogyakarta.

\section{METODE PENELITIAN}

Penelitian yang dilakukan ini adalah penelitian lapangan, dengan menggunakan metode deskripif kualitatif. Penelitian lapangan (field research) adalah penelitian yang terjun langsung pada masalah yang ada kemudian melakukan penelitian secara intensif latar belakang dan keadaan sekarang dan interaksi lingkungan yang terjadi pada suatu satuan sosial seperti: individu, kelompok, lembaga atau komunitas (Fathoni, 2011). 
Penelitian ini dilakukan di Daerah Istimewa Yogyakarya dan LAZISNU Yogyakarta sebagai objek penelitian. Populasi dalam penelitian ini adalah semua mustahik yang menerima zakat produktif dari LAZISNU DIY berjumlah 42 orang.

\section{Teknik Pengumpulan Data}

Pada penelitian ini menggunakan metode pengumpulan data dengan cara sebagai berikut:

\section{Metode Observasi}

Dalam pelaksanaan metode ini akan dilihat pengelolaan zakat produktif di LAZISNU Yogyakarta.

\section{Metode Wawancara}

Dalam pelaksanaan metode ini akan diadakan wawancara dengan pengurus Lembaga Amil Zakat Infak dan Shodaqoh NU Yogyakarta dan para mustahik zakat produktif memperoleh informasi mengenai pengelolaan zakat produktif.

\section{Metode Dokumentasi}

Dalam pelaksanaan metode ini akan dicari dokumen penting dari LAZISNU Yogyakarta. Seperti data berupa laporan hasil pengelolaan dan data berupa tulisan-tulisan penting seperti struktur organisasi, keberadaan amil dan mustahik.

\section{Teknik Analisis Data}

Data penelitian ini akan dianalisis dengan menggunakan Analisis Deskriptif. Penelitian ini bertujuan untuk memberikan gambaran tentang suatu gejala/suatu masyarakat tertentu. Dalam penelitian deskriptif bisa harus diperkecil dan tingkat keyakinan harus maksimal (Sukandarrumudi, 2012).

Dalam pengolahan data agar lebih bermakna dan mudah dipahami, maka analisis datanya menggunakan teori yang dikembangkan oleh Miles dan Huberman (1994). Adapun tahapan-tahapan analisis datanya sebagai berikut:

\section{Data Reduction (Reduksi Data)}

Dalam proses reduksi data ini, dilakukan pemilihan terhadap data yang hendak dikode, mana yang dibuang, mana yang merupakan ringkasan dan cerita-cerita apa yang sedang berkembang.

\section{Data Display (Penyajian Data)}

Setelah data di reduksi, langkah analisis selanjutnya adalah penyajian (display) data. Dalam proses penyajian data ini diarahkan agar data hasil reduksi terorganisasikan, tersusun dalam pola hubungan, sehingga makin mudah dipahami. Penyajian data ini dilakukan dalam bentuk uraian naratif, bagan, hubungan antar kategori, dan lain sebagainya.

\section{Conclusion drawing (Penarikan Kesimpulan)}

Langkah berikutnya dalam proses analisis data kualitatif adalah menarik kesimpulan berdasarkan temuan dan melakukan verifikasi data. Kesimpulan awal yang dikemukakan masih bersifat sementara dan akan berubah bila di temukan bukti-bukti kuat yang mendukung tahap pengumpulan data berikutnya. Proses untuk mendapatkan bukti-bukti inilah yang disebut sebagai verifikasi data. Apabila kesimpulan yang dikemukakan pada tahap awal didukung oleh bukti-bukti yang kuat dalam arti konsisten dengan kondisi yang ditemukan di lapangan maka kesimpulan yang di peroleh merupakan kesimpulan yang kredibel.

\section{HASIL DAN PEMBAHASAN \\ Pengelolaan Dana Zakat Produktif Sumber Dana Zakat Produktif}

Sumber dana zakat produktif diperoleh dari pihak-pihak yang telah bekerjasama dengan LAZISNU yang sebagian besar adalah orang NU. LAZISNU Yogyakarta bekerjasama dengan tokoh-tokoh NU untuk pengumpulan zakat yang nantinya akan disalurkan untuk usaha produktif.

Dari tabel 1 menunjukkan bahwa muzzaki LAZISNU Yogyakarta dari tahun 2015 sampai dengan tahun 2017 mengalami tingkat penurunan. Pada tahun 2015 LAZISNU Yogyakarta terdapat 48 muzzaki, pada tahun 2016 terdapat 44 muzzaki, dan pada tahun 2017 terdapat 38 muzzaki. Tingkat penurunan muzzaki pada LAZISNU Yogyakarta ini dikarenakan bahwa, pada sumber dana yang diperoleh LAZISNU tersebut menggunakan 
Gambar 1. Jumlah Muzaki Tahun 2015 - 2017

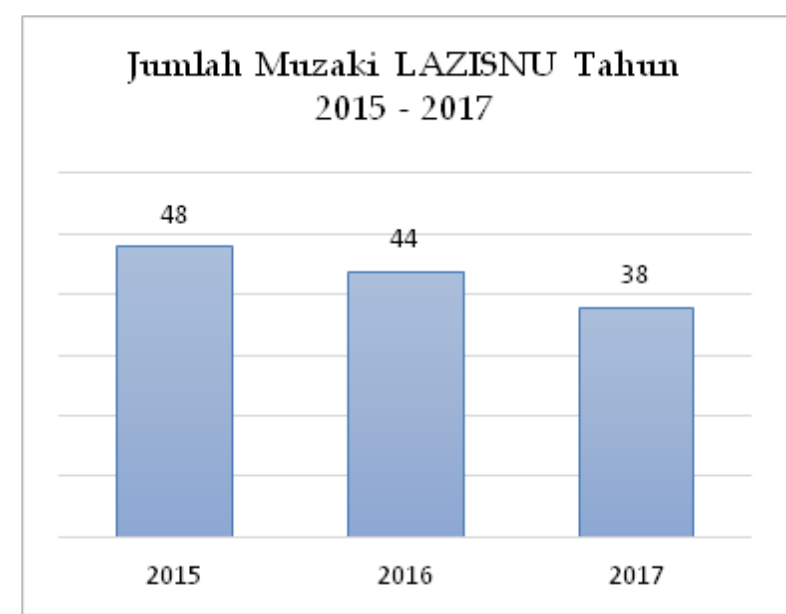

Sumber: Laporan Tahunan LAZISNU Yogyakarta

sistem jumput, dimana pihak muzakki akan menghubungi LAZIS NU untuk mengambil dana zakat tersebut di rumahnya. Sistem jumput ini tidak ditentukan kapan dan tanggal berapa dana zakat tersebut untuk diambil, akan tetapi pihak LAZISNU menunggu dihubungi oeh pihak muzakki (Nuha, 2018).

\section{Pengumpulan Dana Zakat Produktif}

Pengumpulan dana zakat yang di lakukan LAZISNU Yogyakarta yaitu dana zakat produktif yang diperoleh dari muzzaki, yang sudah diberikan kepada LAZISNU Yogyakarta kemudian dikumpulkan terlebih dahulu menjadi satu, yang nantinya dana tersebut akan ditasarufkan kepada mustahik. Mustahik disini terdapat 2 (dua) golongan, yaitu (1) mustahik kelompok, yaitu mustahik yang terdiri dari 4 orang setiap kelompoknya, yang nantinya akan melakukan satu usaha produktif untuk dapat meningkatkan ekonomi mustahik tersebut.

Usaha produktif yang dilakukan oleh mustahik kelompok ada 3 yaitu kelompok ternak ayam jawa super, kelompok ternak kambing dan kelompok kripik. (2) mustahik individu, yaitu mustahik dalam menjalankan usaha produktif tersebut hanya dilakukan satu orang. Adapun usaha yang dijalankan oleh mustahik individu yaitu usaha angkringan, usaha jilbab, dan usaha warung makan.

Pentasarufan dana zakat produktif yang diberikan untuk kelompok mustahik biasanya mencapai Rp 5.500.000,- per kelompoknya.
Sedangkan untuk mustahik yang memiliki usaha individu diberikan modal usaha sekitar Rp 1.000.000 - Rp 2.000.000,- per orangnya, tergantung usaha yang dijalankan mustahik tersebut.

\section{Pentasarufan dana zakat produktif}

Pentasarufan dana zakat produktif yaitu ditasarufkan kepada 8 asnaf yaitu fakir, miskin, amil, muallaf, riqab, gharim, sabilillah, dan ibnu sabil. Akan tetapi LAZISNU sendiri lebih menitik beratkan kepada fakir dan miskin. Adapun proses pentasarufannya yaitu sebagai berikut:

Pencarian mustahik

Pencarian mustahik pada LAZISNU

Yogyakarta dibagi menjadi 2 yaitu:

\section{Pengajuan Proposal}

Proses pencarian mustahik pada LAZISNU Yogyakarta yang pertama adalah melalui pengajuan proposal. Calon mustahik yang ingin mendapatkan zakat produktif untuk dapat menjalankanusaha produktifnya, terlebih dahulu mengajukan proposal baik secara kelompok maupun individu yang nantinya proposal tersebut akan dipertimbangkan setelah survei lokasi usaha. Berikut jumlah prososal dan jenis usaha mustahik dari tahun 2015-2017;

Tabel 1. Jumlah Proposal dan Jenis Usaha

\begin{tabular}{ccc}
\hline Tahun & Jumlah & Jenis Usaha \\
\hline \hline 2015 & 7 & Ternak Ayam dan Keripik \\
2016 & 0 & \\
2017 & 4 & Ternak kambing \\
Total & 11 & \\
\hline
\end{tabular}

Sumber : Laporan Tahunan LAZISNU DIY

\section{Rekomendasi}

Selain pengajuan proposal, LAZISNU Yogyakarta bekerjasama dengan tokoh-tokoh NU atau banom-banom NU seperti MWC (Majelis Wakil Cabang), PC (Pimpinan Cabang), PAC (Pimpinan Anak Cabang) dan tokoh-tokoh NU lainnya. Bekerja sama dengan tokoh-tokoh NU dan Banom-banom NU ini tujuannya untuk dapat merekomendasikan masyarakat yang kurang mampu dan membutuhkan, yang nantinya bisa mendapatkan zakat produktif 
untuk usaha. Berikut jumlah rekomendasi dan jenis usaha mustahik dari tahun 2015-2017;

Tabel 2. Jumlah Rekomendasi dan Jenis Usaha

\begin{tabular}{|c|c|c|}
\hline Tahun & Jumlah & Jenis Usaha \\
\hline 2015 & 16 & $\begin{array}{c}\text { Ternak ayam jawa super dan } \\
\text { ternak kambing }\end{array}$ \\
\hline 2016 & 12 & Ternak ayam dan kambing \\
\hline 2017 & 3 & $\begin{array}{c}\text { Angkringan, jual Jilbab dan } \\
\text { Warung makan }\end{array}$ \\
\hline Total & 31 & \\
\hline
\end{tabular}

Sumber : Laporan Tahunan LAZISNU DIY

Berdasarkan tabel-tabel di atas menunjukan bahwa dari tahun 2015 sampai 2017 jumlah mustahik yang mendapatkan zakat produktif dari LAZISNU DIY adalah 42 orang mustahik, dimana terdiri dari 11 mustahik yang mengajukan proposal dan 33 mustahik yang mendapatkan rekomendasi dari muzakki.

\section{Survei Lokasi}

Survei lokasi dilakukan kepada calon mustahik yang sudah mengajukan proposal maupun yang mendapat rekomendasi dari muzzaki untuk mendapatkan dana usaha produktif. Survei ini dilakukan LAZISNU Yogyakarta untuk mengetahui calon mustahik tersebut benar-benar orang fakir miskin dan mampu untuk menjalankan usaha produktif atau tidak. Apabila mustahik tersebut benar-benar orang fakir miskin dan mampu menjalankan usaha produktif maka mustahik tersebut akan mendapatkan dana zakat untuk usaha produktif. Sedangkan jika calon mustahik tersebut bukan orang fakir miskin dan tidak mampu menjalankan usaha produktif, maka calon mustahik tersebut tidak akan mendapatkan dana zakat produktif.

\section{Pemberian dana zakat produktif}

Tahap selanjutnya setelah di lakukannya survei layak tidaknya mendapatkan dana zakat produtif yaitu memberikan dana zakat produktif untuk usaha kepada mustahik. Mustahik yang diberikan dana zakat produktif atau modal untuk usaha tersebut adalah orangorang yang memang membutuhkan dan sudah layak untuk dibantu. Jumlah mustahik yang mendapatkan zakat produktif dari tahun
2015-2017 adalah 42 orang dengan nominal yang bervariasi, tabel 4 adalah jumlah besaran pemberian zakat produktif yang diterima dari masing-masing mustahik.

\section{Pengawasan dan Pendampingan}

Pengawasan dan pendampingan yang dilakukan oleh LAZISNU Yogyakarta kepada para mustahik dilakukan minimal satu bulan dua kali. Pengawasan dan pendampingan tersebut dengan cara terjun langsung ke lokasi tempat para mustahik menjalankan usaha produktifnya dan dengan cara komunikasi via telepon.

Pengawasan dan pendampingan ini dilakukan agar usaha produktif yang di jalankan oleh para mustahik dapat berjalan dengan lancar dan berkembang, sehingga usaha produktif tersebut dapat meningkatkan ekonomi maupun kesejahteraan mustahik itu sendiri. Jika usaha produktif yang dijalankan oleh para mustahik itu berhasil, maka dapat mengentaskan kemiskinan para mustahik. LAZISNU Yogyakarta sendiri menginginkan mustahik yang diberi dana zakat produktif sekarang bisa menjadi muzzaki di kemudian hari.

Dampak Dari Pengelolaan Zakat Produktif terhadap Kesejahteraan Mustahik

Selama proses pengelolaan zakat produktif yang dilakukan oleh LAZISNU Yogyakarta, tentunya LAZISNU Yogyakarta sudah berusaha melakukan pengelolaan zakat produktif dengan sebaik mungkin untuk mendapatkan hasil yang memuaskan bagi kesejahteraan mustahik. Berikut adalah tingkat kesejahteraan kelompok usaha/jenis usaha mustahik menurut kriteria BKKBN setelah mendapatkan zakat produktif dari LAZISNU Yogyakarta.

Dari tabel 5 menunjukkan bahwa terdapat 4 (empat) tingkatan/tahapan keluarga sejahtera, yaitu (1) tingkat keluarga sejahtera I (Kebutuhan Dasar Keluarga), (2) tingkat keluarga sejahtera II (Kebutuhan Psikologis), (3) tingkat keluarga sejahtera III (Kebutuhan Pengembangan) dan (4) tingkat keluarga sejahtera III Plus (Aktualisasi Diri).

Mustahik yang termasuk pada tingkatan keluarga sejahtera I yaitu 16 mustahik, pada 
Tabel 4. Jumlah Pemberian Zakat Produktif

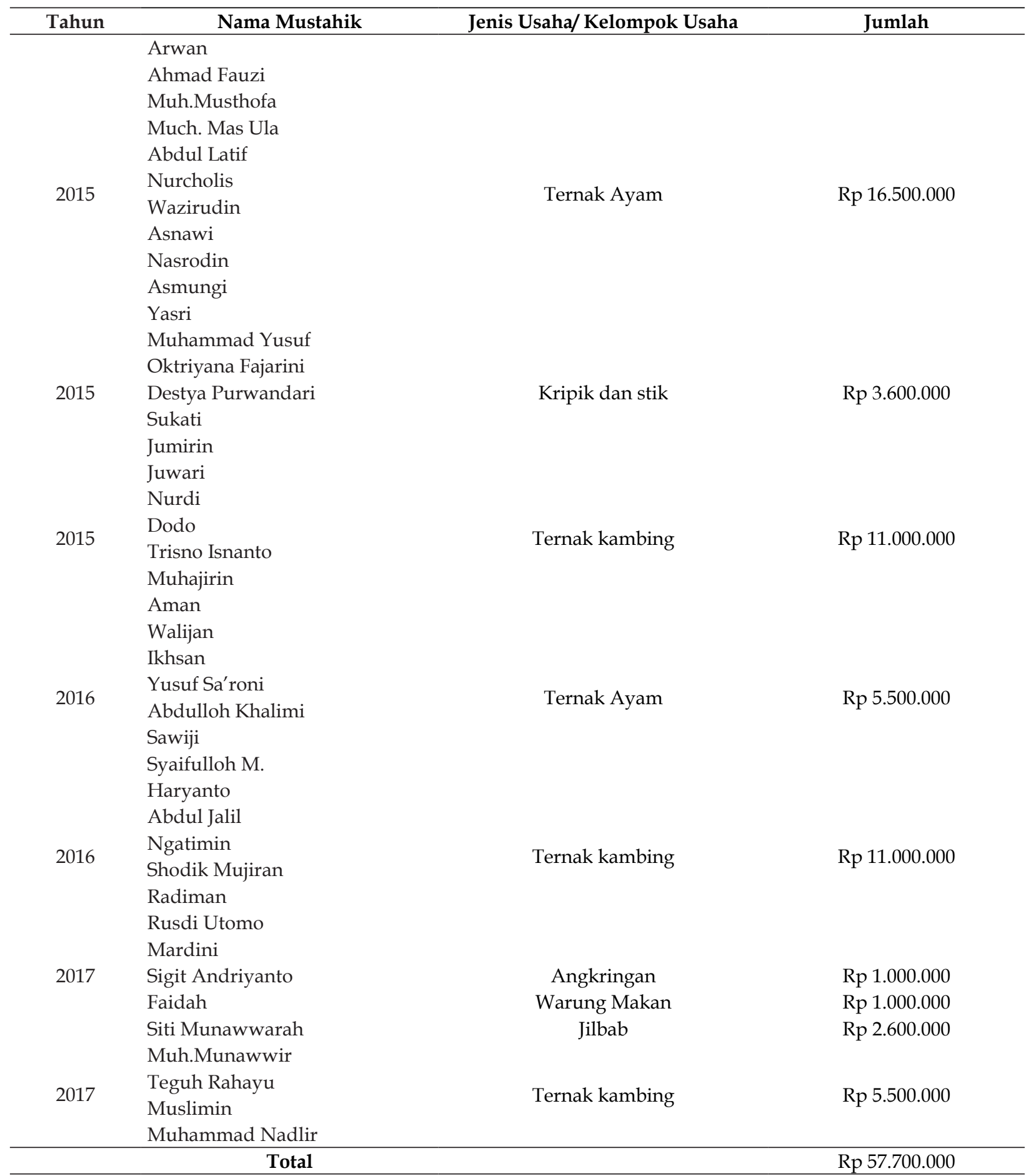

Sumber: Hasil Wawancara dengan mustahik zakat produktif LAZISNU

tingkat keluarga sejahtera II yaitu 12 mustahik, pada tingkat keluarga sejahtera III yaitu 7 mustahik dan pada tingkat keluarga sejahtera yaitu 7 mustahik.

Pada tingkat keluarga sejahtera I (Kebutuhan Dasar Keluarga) terdapat 16 mustahik yang termasuk dalam tingkat keluarga sejahtera I. Adapun 6 indikator tingkat keluarga sejahtera I yaitu sebagai berikut:

Pada Umumnya anggota keluarga makan dua kali sehari atau lebih. Mustahik yang dapat memenuhi indikator pertama dalam tingkat keluarga sejahtera I yaitu 16 


\begin{tabular}{|c|c|c|c|c|}
\hline $\begin{array}{c}\text { Kelompok } \\
\end{array}$ & KS 1 & KS 2 & KS 3 & KS 3 Plus \\
\hline Ternak ayam Desa Miri Pendowoharjo. & 4 & & & \\
\hline Ternak ayam Desa Ngaliyan Ngargosari Samigaluh & & 1 & 1 & 2 \\
\hline Ternak ayam Desa Petet, Ngargosari Samigaluh & 3 & & & 1 \\
\hline Ternak ayam desa Kamal Kulon, Margomulyo Seyegan & & & 1 & 3 \\
\hline Ternak kambing Desa Sareman, Singosaren Bantul & 1 & 2 & 1 & \\
\hline Ternak kambing Desa Karanggayam Segoroyoso Bantul & 1 & & & 3 \\
\hline Ternak kambing Pundung Rt 01 Panggang, Gunungkidul & 1 & & 3 & \\
\hline Ternak kambing Pundung Rt 02 Panggang, Gunungkidul & & 1 & 2 & 1 \\
\hline Ternak kambing Desa Karang, Singosaren Bantul & & 2 & 2 & \\
\hline Usaha Angkringan Ngangglik Patalan Jetis Bantul & & & & 1 \\
\hline Usaha Jilbab Mlangi Sleman & & & 1 & \\
\hline Usaha Warung makan Mlangi Sleman & & & 1 & \\
\hline Usaha kripik dan Stik Desa Karangmojo Gunungkidul & 1 & 1 & & 1 \\
\hline Jumlah & 7 & 7 & 12 & 16 \\
\hline
\end{tabular}

mustahik. Dari ke 16 mustahik tersebut, 3 mustahik pada umumnya makan 2 kali sehari. Sedangkan yang 13 mustahik pada umumnya makan sehari lebih dari dua sampai tiga kali atau lebih.

Anggota keluarga memiliki pakaian yang berbeda untuk dirumah, bekerja/sekolah dan bepergian. Mustahik yang dapat memenuhi indikator ke dua dalam tingkat keluarga sejahtera I yaitu 16 mustahik. Akan tetapi dalam memenuhi indikator tersebut 9 mustahik anggota keluarga memiliki pakaian ganti untuk bekerja, rumah, dan sekolah, 4 mustahik anggota keluarga memiliki pakaian ganti 3 kali sehari, dan 3 mustahik hanya memiliki pakaian 2 kali sehari.

Rumah yang ditempati keluarga mempunyai atap, lantai dan dinding yang baik. Mustahik yang dapat memenuhi indikator ke tiga dalam tingkat keluarga sejahtera I adalah 4 (empat) mustahik. Dari 4 mustahik tersebut sudah memiliki rumah yang baik untuk ditempati. Sedangkan yang belum memenuhi indikator ke tiga ada 12 mustahik, karena penghasilan yang didapatkan belum bisa untuk merehap rumah.

Bila ada anggota keluarga sakit dibawa ke sarana kesehatan. Mustahik yang dapat memenuhi indikator ke empat dalam tingkat keluarga sejahtera I adalah 16 mustahik. Dari keseluruhan mustahik tersebut jika ada anggota keluarganya sakit pasti dibawa ke rumah sakit, puskermas, atau ke bidan.

Bila pasangan usai subur ingin ber KB pergi ke sarana pelayanan kontrasepsi.
Pada indikator yang kelima, mustahik yang memenuhi indakator tersebut ada 10 mustahik. Dari 10 mustahik tersebut semua menggunakan KB, 3 mustahik yang tidak memenuhi indikator tersebut karena tidak ingin menunda punya anak dan tidak ingin menggunakan KB. Sedangkan ada 3 mustahik yang tidak memenuhi indikator tersebut karena belum mempunyai istri.

Semua anak umur 7-15 tahun dalam keluarga bersekolah. Pada indikator yang keenam, mustahik yang memenuhi indakator tersebut ada 8 mustahik. Keseluruhan mustahik tersebut mempunyai anak yang masih bersekolah. Ada 3 mustahik yang tidak memenuhi indikator tersebut karena belum menikah. Ada juga 3 mustahik yang tidak memenuhi indikator tersebut karena anaknya masih balita.

Pada tingkat keluarga sejahtera II (Kebutuhan Psikologis) terdapat 12 mustahik yang termasuk pada tingkatan tersebut. Adapun 8 indikator keluaga sejahtera II yaitu sebagai berikut:

Pada umumnya anggota keluarga melaksanakan ibadah sesuai dengan agama dan kepercayaan masing-masing Mustahik yang dapat memenuhi indikator pertama dalam tingkat keluarga sejahtera II adalah 12 mustahik. Mustahik tersebut pada umumnya beragama Islam dan dapat melaksanakan ibadah sholat sesuai dengan kepercayaannya

Paling kurang sekali dalam seminggu seluruh anggota keluarga makan daging/ ikan/telur. Mustahik yang dapat memenuhi 
indikator ke dua pada tingkat keluarga sejahtera II adalah 8 mustahik. Mustahik tersebut pada umumnya selama satu minggu sekali makan dengan lauk daging/ikan dan telur. Sedangkan 4 mustahik lainnya tidak dapat memenuhi indikator ke dua dalam tingkat keluarga sejahtera II, karena ekonomi para mustahik tersebut masih rendah, dan hanya dapat membeli lauk seadanya saja.

Seluruh anggota keluarga memperoleh paling kurang satu stel pakaian baru dalam setahun. Mustahik yang dapat memenuhi indikator ke tiga dalam tingkat keluarga sejahtera II adalah 8 mustahik. Para mustahik tersebut minimal dalam jangka waktu satu tahun sekali memperoleh satu stel pakaian baru, yang diperoleh dari orang lain maupun beli sendiri. Sedangkan 4 mustahik lainnya belum memenuhi indikator ke tiga dalam tingkat keluarga sejahtera II karena penghasilan yang didapatkan oleh mustahik hanya cukup untuk memenuhi kebutuhan sehari-hari.

Luas lantai rumah paling kurang $8 \mathrm{~m} 2$ untuk setiap penghuni rumah. Mustahik yang dapat memenuhi indikator ke empat dalam tingkat keluarga sejahtera II adalah 9 mustahik. Para mustahik tersebut memiliki rumah yang ukurannya lebih dari $8 \mathrm{~m}^{2}$. Sedangkan 3 mustahik lainnya belum bisa memenuhi indikator ke empat dalam tingkat keluarga sejahtera II, karena tidak mempunyai lahan yang luas untuk pembangunan rumah.

Tiga bulan terakhir keluarga dalam keadaan sehat sehingga dapat melaksanakan tugas dan fungsi masing-masing. Mustahik yang dapat memenuhi indikator ke lima dalam tingkat keluarga sejahtera II adalah 6 mustahik. Para mustahik tersebut diberikan kesehatan oleh Allah SWT, sehingga dapat melaksanakan kegiatannya.

Adanya seorang atau lebih anggota keluarga yang bekerja untuk memperoleh penghasilan. Mustahik yang dapat memenuhi indikator ke enam dalam tingkat keluarga sejahtera II adalah 12 mustahik. Keseluruhan mustahik tersebut pada umumnya salah satu anggota keluarga bekerja untuk memperoleh penghasilan.

Seluruh anggota keluarga umur 1060 tahun bisa baca tulisan latin. Mustahik yang dapat memenuhi indikator ke tujuh dalam tingkat keluarga sejahtera II adalah 12 mustahik. Keluarga para mustahik tersebut dapat membaca dan menulis latin semua.

Pasangan usia subur dengan anak dua atau lebih menggunakan alat/obat kontrasepsi. Mustahik yang dapat memenuhi indikator ke delapan dalam tingkat keluarga sejahtera II adalah 10 mustahik. Para mustahik tersebut menggunakan alat/obat kontrasepsi. Sedangkan 2 mustahik lainnya tidak dapat memenuhi indikator ke delapan dalam tingkat keluarga sejahtera II.

Pada tingkatan keluarga sejahtera III (Kebutuhan Pengembangan) terdapat 7 mustahik yang dapat memenuhi indikator tersebut. Adapun 5 indikator tersebut adalah sebagai berikut:

Keluarga berupaya meningkatkan pengetahuan agama. Mustahik yang dapat memenuhi indikator pertama dalam tingkat keluarga sejahtera III yaitu 7 mustahik. Mustahik tersebut dapat memenuhi indikator karena dapat meningkatkan pengetahuan agama dengan cara mengikuti pengajian di daerah masing-masing mustahik.

Sebagian penghasilan keluarga ditabung dalam bantuk uang atau barang. Mustahik yang dapat memenuhi indikator ke dua yaitu 7 mustahik. Dari ke 7 mustahik tersebut, ada 2 mustahik yang dapat memenuhi indikator tersebut dengan cara menabung sebagian harta dalam bentuk uang. Sedangkan 5 mustahik yang dapat memenuhi indikator tersebut dengan nabung sebagian hartanya dalam bentuk hewan ternak.

Kebiasaan keluarga makan bersama paling kurang seminggu sekali dimanfaatkan untuk berkomunikasi. Mustahik yang dapat memenuhi indikator ke tiga dalam tingkat keluarga sejahtera III yaitu 7 mustahik. Mustahik tersebut selama satu minggu satu kali biasanya makan bersama dengan keluarganya.

Keluarga ikut dalam kegiatan masyarakat di lingkungan tempat tinggal. Mustahik yang dapat memenuhi indikator ke empat dalam tingkat keluarga sejahtera III adalah 5 mustahik. Para mustahik tersebut selalu mengikuti kegiatan masyarakat di lingkungan tempat tinggal masing-masing mustahik. Biasanya ikut dalam kegiatan gotong royang.

Keluarga memperoleh informasi dari surat kabar/majalah/radio/tv/internet. 
Mustahik yang dapat memenuhi indikator ke lima dalam tingkat keluarga sejahtera III yaitu 5 mustahik. Para mustahik tersebut mendapatkan berbagai informasi dari dua sumber, yaitu televisi dan hp.

Pada tingkatan keluarga sejahtera III Plus (Aktualisasi diri) terdapat 7 mustahik yang termasuk dalam tingkat tersebut. Tingkatan keluarga sejahtera III memiliki 2 indikator, yaitu sebagai berikut:

Keluarga secara teratur dengan suka rela memberikan sumbangan materiil untuk kegiatan sosial. Mustahik yang dapat memenuhi indikator pertama dalam tingkat keluarga sejahtera III Plus yaitu 7 mustahik. Mustahik tersebut dapat menyisihkan sebagian hartanya untuk disumbangkan pada kegiatan sosial dimasyarakat.

Ada anggota keluarga yang aktif sebagai pengurus perkumpulan sosial/ yayasan/ institusi masyarakat. Mustahik yang dapat memenuhi indikator ke dua dalam tingkat keluarga sejahtera III Plus yaitu 7 mustahik. Dari ke 7 mustahik tersebut, 4 antaranya ada yang menjadi pengurus pondok pesantren. Ada 2 mustahik yang memenuhi indikator tersebut karena ikut aktif sebagai pengurus Karangtaruna di desa masing-masing mustahik. Sedangkan satu mustahik yang dapat memenuhi indikator tersebut karena ikut serta dalam pengurus PKK (Pembinaan Kesejahteraan Keluarga) di lingkungan desa tersebut.

Adapun prosentase tingkat keluarga sejahtera mustahik zakat produktif LAZISNU Yogyakarta adalah sebagai berikut:

\section{Gambar 2. Persentase Tingkat Keluarga} Sejahtera Mustahik

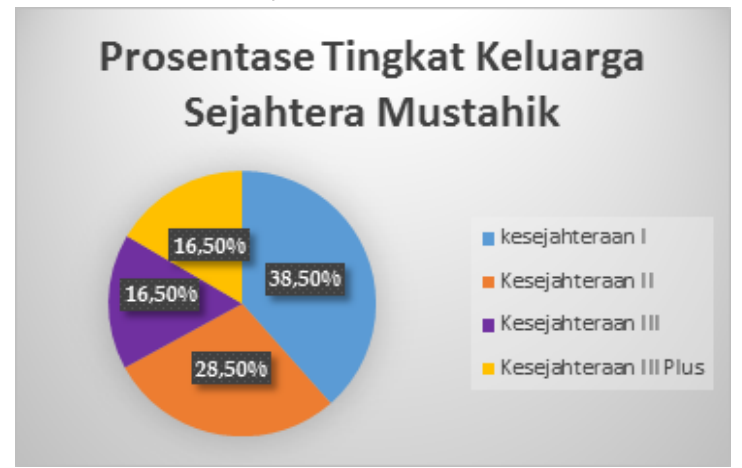

Sumber: Hasil survei dan wawancara mustahik zakat produktif LAZISNU
Dari diagram di atas menunjukkan bahwa prosentase tingkat keluarga sejahtera I adalah 38,5\%, tingkat keluarga sejahtera II adalah $28,5 \%$, tingkat keluarga sejahtera III adalah, $16,5 \%$, dan tingkat keluarga sejahtera III Plus adalah $16,5 \%$.

Hasil prosentase tersebut dihitung dari jumlah tingkat keluarga sejahtera masingmasing mustahik dibagi dengan jumlah keseluruhan mustahik dan dikalikan dengan $100 \%$. Sehingga tingkat keluarga sejahtera dapat ditentukan dengan prosentasenya.

\section{KESIMPULAN}

Berdasarkan hasil penelitian dan pembahasan, maka dapat ditarik kesimpulan sebagai berikut:

\section{Pengelolaan Dana Zakat Produktif di LAZISNU Yogyakarta}

Dana zakat produktif di LAZISNU Yogkarta diberikan untuk usaha-usaha zakat produktif yaitu usaha ternak ayam, usaha ternak kambing, usaha kripik, usaha jilbab, usaha warung makan, dan usaha angkringan. Adapun tahapan-tahapan dalam pengelolaan dana zakat di LAZSINU Yogyakarta yaitu: (1) Sumber dana zakat produktif. Sumber dana diperoleh dari pihak-pihak yang telah memberikan dana zakat produktif pada LAZISNU, yang nantinya sumber dana tersebut akan disalurkan untuk usaha produktif. (2) Pengumpulan dana zakat. Dana zakat yang diberikan oleh muzzaki dikumpulkan terlebih dahulu sebelum dana tersebut ditasarufkan kepada mustahik. (3) Pentasarufan dana zakat produktif. LAZISNU menasarufkan dana zakat produktif dalam bentuk uang maupun bahan baku, yang nantinya dapat digunakan untuk menjalankan usaha masing-masing mustahik. Pentasarufan dana dari LAZISNU diberikan kepada 8 asnaf yaitu fakir, miskin, amil, muallaf, riqab, gharim, sabilillah, dan ibnu sabil. Akan tetapi LAZISNU sendiri lebih menitik beratkan pentasarufan dana zakat diberikan kepada fakir dan miskin. Adapun proses penasarufannya yaitu pencarian mustahik, pengajuan proposal, survei lokasi, dan pentasarufan dana zakat produktif. (4) Pengawasan dan Pendampingan. LAZISNU 
Yogyakarta tidak serta merta memberikan dana zakat produktif kepada mustahik, akan tetapi LAZISNU Yogyakarta juga memberikan pengawasan dan pendampingan pada mustahik. Pengawasan dan pendampingan ini dilakukan agar usaha produktif yang dijalankan oleh para mustahik dapat berjalan dengan lancar dan berkembang, sehingga usaha tersebut dapat meningkatkan ekonomi dan kesejahteraan mustahik.

\section{Dampak zakat produktif terhadap kesejahteraan mustahikdi LAZISNU Yogyakarta}

Dampak zakat produktif terhadap kesejahteraan mustahik yang di LAZISNU Yogyakarta yaitu dibagi menjadi 4 (empat) Tingkat Keluarga Sejahtera. Adapun 4 tingkat keluarga sejahtera yaitu: Tingkat Keluarga Sejahtera I (Pemenuhan Kebutuhan), Tingkat Keluarga Sejahtera II (Kebutuhan Psikologi), Tingat Keluarga Sejahtera III (Kebutuhan Pengembangan), dan Tingkat Keluarga Sejahtera III Plus (Aktualisasi Diri).

Tingkat keluarga sejahtera I yaitu pemenuhan kebutuhan dasar sebanyak 38,5\%, tingkat keluarga sejahtera II yaitu kebutuhan psikologis sebanyak 28,5\%, tingkat keluarga sejahtera III adalah kebutuhan pengembangan sebanyak $16,5 \%$, dan tingkat keluarga sejahtera III plus adalah aktualisasi diri sebanyak $16,5 \%$. Sedangkan ada beberapa mustahik yang merasa terbantu dengan adanya zakat produktif dari LAZISNU sehingga dapat merasakan adanya peningkatan kesejahteraan perekonomian

\section{DAFTAR PUSTAKA}

Fajri, P.P. Ahmad, "Pengaruh Pendayagunaan Zakat Produktif Terhadap Pemberdayaan Mustahiq Pada Badan Pelaksana Urusan Zakat Amwal Muhammadiyah (BAPELURZAM) Pimpinan Cabang Muhammadiyah Weleri
Kabupaten Kendal", Skripsi S1, Semarang: IAIN Walisongo Semarang, 2010

Fathoni. Abdurrahmat, Metodologi Penelitian dan Teknik Penyusunan Skripsi, Jakarta: Rineka Cipta, 2011

Fitri. Maltuf, "Pengelolaan Zakat ProduktifSebagai Instrumen Peningkatan Kesejahteraan Umat", Jurnal Ekonomi Islam, Vol 08. No.01, 2017 Khasanah, Umrotul, "Manajemen Zakat Modern Instrumen Pemberdayaan Ekonomi Umat", Malang: UIN Maliki Press, 2010.

Kholis, Noor, Sobaya, Andriansyah, Iqbal, Muhammad, "Potret Filantropi Islam di Propinsi Daerah Istimewa Yogyakarta", Jurnal Ekonomi Islam La Riba, Vol. VII, No. 1 Juli 2013

Miles, B., Matehew dan Huberman, Michael, A., , Qualitative Data Analysis: A Sourcebook of New Methods, London: Sage Publications, 1994

Nafiah. Lailiyatun, "Pengaruh Pendayagunaan Zakat Produktif Terhadap Kesejahteraan Mustahiq Pada Program Ternak bergulir Baznas Kabupaten Gresik", Jurnal Ekonomi Islam eL-Qist, Vol. 05, No. 01, April 2015

Nuha, Ulin, Pengurus LAZISNU Yogyakarta, wawancara pada tanggal 17 Januari 2018

Ramadhan, Zaky, "Peran BAZNAS Dalam Pengentasan Kemiskinan Di Daerah Istimewa Yogyakarta", Skripsi SI, Yogyakarta: UIN Sunan Kalijaga Yogyakarta, 2016

Sartika, Mila, "Pengaruh Pendayagunaan Zakat Produktif terhadap Pemberdayaan Mustahiq pada LAZ Yayasan Solo Peduli Surakarta", Jurnal Ekonomi Islam La Riba, Vol. II, No. 1 Juli 2008

Soemitra, Andri, Bank \& Lembaga Keuangan Syariah, Jakarta: Kencara Prenada Media Group, 2009

Sukandarrumudi, S, Metode Penelitian Petujuk Praktis Untuk Peneliti Pemula, Yogyakarta: Gadjah Mada University, 2012

Www.yogyakarta.bps.go.id 